DOI https://doi.org/10.30525/978-9934-26-007-0-10

\title{
ГУМАНІЗМ ЯК ПРИНЦИП ПРАВОТВОРЧОСТІ: ТЕОРЕТИКО-ПРАВОВІ ЗАСАДИ
}

\section{Донченко О. I.}

\section{ВСТУП}

Правотворчість як процес творення норм права $\epsilon$ досить важливим i складним явищем, яке потребує переосмислення та вироблення ефективних, науково обгрунтованих шляхів свого вдосконалення. Комплексне наукове дослідження правотворчих процесів передбачає дослідження всіх аспектів, що характеризують порядок розроблення, ухвалення та введення в дію нормативно-правових актів. Одним із важливіших напрямів $є$ дослідження принципів правотворчості, їх змісту та системи.

Такі принципи правотворчої діяльності, як законність, демократизм, науковість, професіоналізм, гласність, наступність, оперативність, системність, дотримання юридичної техніки, випереджаючого реагування правотворчої політики, відображення суспільної думки та концептуальності правотворчої політики тощо ${ }^{1}, \epsilon$ невід’ємними від неї, забезпечують ії ефективність та являють собою фундаментальні положення, які покладені в її основу.

Визначальне місце в системі принципів правотворчості належить принципу гуманізму, утілення у правотворчу практику якого пов'язано 3 основними вимогами формування та розвитку громадянського суспільства, правової держави, а також ефективного функціонування всієї правової системи, оскільки він відіграє вихідну роль у системі основоположних принципів права та забезпечує системний взаємозв'язок між ними.

Під час дослідження принципу гуманізму в контексті правотворчої діяльності варто звернути увагу на вимоги щодо адекватного відображення у змісті нормативно-правових актів загальнолюдських цінностей, закріплення в них основних соціальних умов ефективної реалізації прав і свобод людини і громадянина, їхньої рівності, вчасний захист та відповідність ухвалених норм міжнародним стандартам. Отже, у процесі здійснення правотворчості в усіх формах (законодавча діяльності та підзаконна правотворча діяльність) уповноваженими суб'єктами мають бути реалізовані всі вимоги принципу гуманізму, проте в реальному житті можемо спостерігати особливості і колізії їх відображення в деяких галузях права.

\footnotetext{
${ }^{1}$ Чабур С.В. Принципи правотворчості. Вісник Чернівецьького факультету Національного університету «Одеська юридична академія». 2017. Вип. 2. С. 72.
} 


\section{1. Теоретичні засади гуманізму як принципу правотворчості}

Гуманізм є об'єктом дослідження багатьох галузей науки, зокрема: історії, філософії, соціології, політології, педагогіки тощо. У найширшому сенсі слова гуманізм являє собою «інтелектуальну конструкцію, продукт думок, продукт світоглядів, продукт добре збудованого, логічного завершеного мислення» ${ }^{2}$. Погоджуємося 3 B.О. Нікітенко щодо того, що проблема людини і гуманізм є тим вузловим пунктом, до якого «стягуються» усі проблеми нашого суспільства - відчуження людини від влади і суспільства, деструктивні процеси в суспільстві, що позбавляють людину гідного існування і сприяють порушенню прав і свобод особистості тощо.

У юриспруденції гуманізм виступає як принцип права, як вихідний i такий, що пов'язує, компонент між усіма принципами права, що дозволяє імплементувати та трансформувати його вимоги до всіх державно-правових категорій.

У правотворчій діяльності гуманізм $є$ підгрунтям і основоположною засадою для інших принципів, зокрема законності, демократизму, гласності, відображення суспільної думки тощо.

Варто зазначити, що в теорії права $є$ низка понять, зміст яких треба розмежовувати під час розгляду принципів правотворчості. Це принципи права, принципи правотворчості та принципи, закріплені в нормативноправових актах.

Погоджуємося 3 тим, що принципи права - це своєрідна система координат, у межах якої розвивається право, або вектор, що визначає напрям розвитку права. Вони відображають світовий досвід розвитку права i досвід цивілізації; вони слугують нормативними основами права, можуть бути прямо сформульовані в законодавчих актах чи виникати із загального змісту таких актів, зумовлювати тим самим напрями правотворчої, правозастосовної й іншої юридичної діяльності ${ }^{3}$.

B.M. Косович у процесі дослідження питання щодо розмежовування принципів права, принципів правотворчості та принципів, закріплених у нормативно-правових актах, зазначає, що деякі розбіжності у визначенні цих понять об'єктивно зумовлені, оскільки вони передбачають різні правові явища: засади права в загальноюридичному розумінні, засади одного з різновидів юридичної діяльності та засади конкретного нормативноправового акта. Ці розбіжності не передбачають їхньої невідповідності. Автором зазначено, що «змістова відповідність принципів права,

\footnotetext{
${ }^{2}$ Нікітенко В.О. Гуманізм як фундаментальна тенденція суспільного розвитку: теорія та практика. Гуманітарний вісник Запорізької державної інженерної академії. 2005. Вип. 22. С. 181.

3 Амеліна А.С. Принципи кодифікації цивільного законодавства. Науковий вісник Ужсгородського національного університету. Серія «Право». 2015. Вип. 30 (1). С. 107.
} 
правотворчості та нормативно-правових актів простежується через характеристику правових явищ, окреслених принципами, позначеними термінами «верховенство права» та «гуманізм»»» ${ }^{4}$.

Як зазначає B.M. Косович, терміни «верховенство права» та «гуманізм» у науковій літературі вживаються і як окремі, і як паралельні, проте «визначення змісту понять, позначених цими термінами, вказує на їх єдність, оскільки в них ідеться про необхідність пріоритету загальновизнаних невід'ємних прав та свобод людини i громадянина у сфері юридичного регулювання суспільних відносин» ${ }^{5}$. Далі автор, 3 посиланням на розвідки інших дослідників, підкреслює, що принцип гуманізації права це поступове втілення в норми права загальнолюдських принципів права, розширення законодавчого закріплення основних прав людини, піднесення рівня соціальної справедливості правового регулювання тощо.

Якщо повернутися до такої вимоги, як справедливість, слушною здається теза О.М. Юхимюк у науковому дослідженні щодо способів викладу принципів права в нормативно-правових актах. Так, автором зазначено, що у принципах права, що виражені в нормативно-правових актах, законодавцем вкладено формулу справедливості та директиву, що зобов’язує дотримуватись цієї формули. Як приклад наводяться дві статті Конституції це ст. 61, якою передбачено, що ніхто не може бути двічі притягнений до юридичної відповідальності одного виду за те саме правопорушення, та ст. 24, якою передбачено, що громадяни мають рівні конституційні права i свободи та є рівними перед законом. Отже, ст. 61 містить положення, яке, на думку автора, по суті є вираженням принципу справедливості, а ст. 24 тлумачиться як директива, що зобов'язує державні органи дотримуватись певної формули справедливості в певній сфері суспільного життя. «У такому разі принципом права потрібно вважати не саму формулу справедливості, а директиву, що зобов'язує дотримуватись цієї формули» 6 .

Справді, верховенство права, що є фундаментальним принципом правової держави, зумовлює й інші принципи, зокрема підпорядкування закону самої держави та ії органів, посадових осіб, інших організацій, громадян, але цей закон має бути виключно «справедливим, гуманним, закріплювати невід’ємні природні права кожної людини: право на життя, на свободу, на особисту недоторканість» 7 .

\footnotetext{
${ }^{4}$ Косович В.М. Принципи права, принципи правотворчості та принципи у нормативно-правових актах. Вісник Львівського університету. Серія «Юридична». 2016. Вип. 63. С. 5.

${ }^{5}$ Там само.

${ }^{6}$ Юхимюк О.М. Способи викладу принципів права у нормативно-правових актах. Історико-правовий часопис. 2014. № 2. С. 25.

7 Чепульченко Т.О. Верховенство права як основоположний принцип сучасного правотворення. Вісник Національного технічного університету Украйни «Киӥвський політехнічний інститут». Серія «Політологія. Соціологія. Право». 2012. № 3. С. 186.
} 
Погоджуємося з Т.О. Чепуленко щодо того, що верховенство права - це конституційний принцип, який виступає своєрідною межею для всіх органів влади, що стримує можливі зазіхання на людські цінності, а також це «вказівка на пріоритет природних прав людини в державі».

Н.В. Конєва розглядає природно-правовий зміст правового закону й у своєму науковому дослідженні підсумовує, що «саме природні права людини є головним критерієм визнання закону правовим та предметним критерієм правового характеру законодавства, що, у свою чергу, детермінують можливість його реалізації в дусі забезпечення основних прав і свобод людини та громадянина» ${ }^{8}$.

Слушною здається і думка Н.О. Славової, яка зазначає, що «гуманізм - це визнання людини вищою соціальною цінністю за допомогою визначення та захисту їі прав, свобод через правотворчість» ${ }^{9}$, тобто нормативно-правові акти, як результат правотворчої діяльності, мають відображати загальнолюдські цінності.

Отже, принципи права, принципи правотворчості та принципи, закріплені в нормативно-правових актах, не існують зовсім ізольовано, а навпаки мають властивість взаємопроникнення.

Як уже було зазначено в попередніх дослідженнях, правотворчість $\epsilon$ водночас і діяльністю, і явищем, і процесом, які «напряму пов'язані 3 формою і типом держави, механізмом реалізації іiі функцій, особивостями системи права, рівнем правової свідомості та правової культури суб'єктів права тощо» ${ }^{10}$, тобто такий взаємозв'язок правотворчої діяльності 3 усіма елементами правової системи передбачає також певний динамізм iii принципів, і принцип гуманізму не $є$ винятком. Справді, багато дослідників розглядають феномен гуманізму як відкриту систему, що активно розвивається і трансформується. У дослідженні принципів нормотворчої діяльності органів виконавчої влади Є.А. Гетьман зазначає, що «принципам притаманна певна динамічність, тобто вони змінюються залежно від рівня правового, культурного, соціального розвитку держави та $\dddot{1 і ̈ ~ с у с п і л ь с т в а » ~}{ }^{11}$.

У науковому дослідженні гуманізму як феномену i як світоглядного принципу нової парадигми освіти С.М. Жуков, який зробив аналіз багатьох думок і поглядів щодо зазначеного питання, звертає увагу на те, що

\footnotetext{
${ }^{8}$ Конєва Н.В. Природно-правовий зміст правового закону. Науковий вісник Начіональної академії внутрішніх справ. 2013. № 2. С. 99.

${ }^{9}$ Славова Н.О. Антропоцентризм як принцип правотворчості. Правничий часопис Донецьвкого університету. 2013. № 1. С. 135.

${ }^{10}$ Особливості і проблеми розвитку правотворчості в сучасних умовах : монографія / О.І. Донченко та ін. ; за заг. ред. В.П. Плавича. Одеса : Феникс, 2018. С. 232.

11 Гетьман Є.А. Принцип верховенства права у нормотворчій діяльності органів виконавчої влади. Проблеми законності. 2016. Вип. 134. С. 65.
} 
гуманізм - це відкрита система, що динамічно розвивається, охоплює погляди, уявлення, моральні принципи, які заперечують усі види нерівності між індивідуумом та суспільством, а також практичні дії, які «реалізують цей принцип в економічній, політичній і юридичній сферах буття» ${ }^{12}$. Оскільки ця система динамічна та відкрита, то цілком закономірним $є$ те, що вона наповнюється різним змістом у різні історичні епохи, піддається трансформації та змінам.

У науковому дослідженні Н.В. Шакун «Гуманізм як духовно-моральний вимір соціальної роботи» автором зазначено, що «на різних етапах історичного поступу ідеї гуманізму набували специфічного тлумачення, що суттєво урізноманітнило їхній зміст, нині співіснує безліч гуманістичних ідей та концепцій: світська, теологічна, ідеалістична, матеріалістична, песимістична, оптимістична, конформістська тощо, але головними вимогами $\epsilon$ визнання людини найвищою цінністю, поважання людської особистості, ii гідності, прагнення забезпечити та гарантувати основні права особистості, підтримка знедолених, соціально «вразливих» громадян тощо ${ }^{13}$.

Властивий гуманізму історично конкретний характер визнає і М.М. Сисак, якою в дослідженні гуманізму в контексті глобалістики щодо питання, як новий гуманізм зможе реально втілитися в життя, звернено увагу, «що гуманізм в даному разі розглядається як норма людської солідарності та $\epsilon$ формулою загального благополуччя» ${ }^{14}$, для чого важливим $€$ визнання загальних етичних норм та подолання розбіжності між народами.

Погоджуємося, що гуманізм - це принцип і показник рівня цивілізованості людини і суспільства, що пронизує всі сфери людської життєдіяльності, має універсальний космополітичний характер, належить до основних соціальних цінностей і виражається через такі категорії, як «справедливість», «рівність», добро», «права і обов'язки людини» 15 .

\section{2. Відображення гуманізму як принципу правотворчості в конституційному та цивільному праві}

Розглянемо відображення і вплив основних вимог гуманізму як принципу правотворчої діяльності в деяких галузях права. Варто звернути увагу на те, що принцип гуманізму може і не бути сформульований прямо в нормі тієї чи іншої галузі права, проте його вимоги випливають зі змісту правових

\footnotetext{
12 Жуков С.М. Гуманізм як феномен, як світоглядний принцип нової парадигми освіти; гуманістичне виховання, становлення підростаючої особистості. Педагогічна освіта: теорія і практика, 2011. Вип. 9. С. 39.

13 Шакун Н.В. Гуманізм як духовно-моральний вимір соціальної роботи Проблеми соціальної роботи: філософія, психологія, соиіологія. 2013. № 1. С. 35

${ }_{14}$ Сисак М.М. Гуманізм в контексті глобалістики. Гілея : науковий вісник. 2014. Вип. 80. С. 302.

15 Ричко О.В. Принцип гуманізму в публічній політиці. Збірник наукових працьь Національної академії державного управління при Президентові Украӥни. 2012. Вип. 2. С. 228.
} 
норм, лежать в основі побудови галузі права або мають бути виявлені за змістом нормативно-правового акта.

Звернемося до галузі конституційного права, оскільки реалізація всіх вимог принципу гуманізму забезпечується і гарантується насамперед Конституцією України. Як зазначається в наукових дослідженнях, принцип гуманізму - це конституційний принцип, оскільки визнаний на міжнародному рівні, задекларований у Конституції та пронизує всі галузі права, усю правову систему будь-якої цивілізованої держави ${ }^{16}$, тобто Конституція і є гарантією забезпечення та реалізації гуманістичних засад правотворчої роботи.

У науковому дослідженні презумпції правового характеру законів у правовій державі автором М.В. Тесленко зазначено, що «гуманістична концепція відповідного закону будується на проголошенні прав і свобод людини і громадянина, які є загальнообов'язковим стандартом діяльності держави» ${ }^{17}$, тобто правовий характер законів випливає 3 Конституції, хоча Конституція України не містить терміна «правовий закон».

Варто згадати ст. 3 Конституції України, де закріплено, що «людина, їі життя і здоров'я, честь і гідність, недоторканність і безпека визнаються в Україні найвищою соціальною цінністю» ${ }^{18}$, що передбачає визнання соціальною цінністю людської особистості, проголошення та захист її прав, свобод, законних інтересів та забезпечення гарантій їх реалізації.

Усі ухвалені нормативно-правові акти мають відповідати Конституції, чинним законам, ратифікованим міжнародним договорам чи угодам, а також загальним принципам міжнародного права. Так, ст. 8 Основного закону України встановлено, що Конституція має найвищу юридичну силу, а всі інші нормативно-правові акти ухвалюються на її основі та мають відповідати їй.

Отже, у процесі творення норм права будь-яким суб'єктом правотворчої діяльності в будь-якій галузі вкрай важливу і вихідну роль відіграє принцип гуманізму, реалізація вимог якого забезпечується і гарантується насамперед Конституцією України, де визначено пріоритет загальнолюдських цінностей, закріплено принципи соціальної справедливості, утверджений демократичний і гуманістичний вибір народу України, задекларовано прихильність України до загальновизнаних норм міжнародного права.

Можемо сказати, що гуманістичне начало виступає стрижневим принципом будь-якої форми правотворчості в будь-якій галузі права, тобто шляхом ухвалення нового нормативно-правового акта, яким встановлюються нові, змінюються або припиняють свою дію чинні норми права,

\footnotetext{
${ }^{16}$ Чеботарьов С.С. Гуманізм як принцип права України. Актуальні проблеми держави і права. 2012. Вип. 65. С. 208.

${ }^{17}$ Тесленко М.В. Презумпція правового характеру законів у правовій державі. Актуальні проблеми держави і права. 2004. Вип. 22. С. 225.

${ }^{18}$ Конституція України, ухвалена 28 червня 1996 р., зі змінами.
} 
відповідні суб'єкти правотворчої діяльності встановлюють умови реалізації громадянами своїх прав і свобод.

Отже, гуманізм як принцип правотворчої роботи конкретизується в таких складових частинах, як відображення в нормативно-правових актах загальнолюдських цінностей, закріплення в них основних соціальних умов реалізації прав і свобод людини і громадянина, адекватний баланс інтересів усіх учасників правовідносин, їхня рівність, вчасний захист та відповідність ухвалених нормативно-правових актів міжнародним договорам і стандартам.

Погоджуємося, що практичне дотримання у процесі нормотворчості (що охоплює правотворчість і законотворчість) ії принципів - це невелика, але гарантія якості ухвалених нормативно-правових актів, що «поряд із належним правозастосуванням, як відомо, є гарантією якості суспільного буття як загалом, так і в різних його галузях» ${ }^{19}$.

У цивільному праві складові частини принципу гуманізму охоплюють такі засади, як неприпустимість свавільного втручання у сферу особистого життя людини, неприпустимість безпідставного позбавлення права власності, свобода договору, свобода підприємницької діяльності, судовий захист цвільного права й інтересу, справедливість, добросовісність, розумність тощо.

У науковому дослідженні принципів цивільного законодавства О.В. Басай зазначає, що вітчизняна правотворчість рухається шляхом подальшого текстуального закріплення принципів права, які безпосередньо не містяться в нормі, а виводяться 3 певної групи правових норм, але всі принципи цивільного права мають загальнообов'язковий характер, «їх дотримання $\epsilon$ обов'язковим як у законотворчості, так і у правозастосуванні» ${ }^{20}$.

Як слушно зазначає С.М. Мельничук, правотворчість, як процес творення норм права, забезпечує функціонування держави, «правова система якої орієнтована на розуміння права як загальнообов'язкової форми рівності, свободи і справедливості, де критерієм є сама людина, iї права і свободи» ${ }^{21}$, що становить зміст і сутність будь-якого нормативно-правового акта. Що стосується інституту соціального обслуговування в галузі права соціального забезпечення, то варто нагадати про нещодавно ухвалений Закон «Про соціальні послуги», у преамбулі якого зазначено, що він «визначає основні організаційні та правові засади надання соціальних послуг, спрямованих на профілактику складних життєвих обставин, подолання або мінімізацію їх негативних наслідків, особам/сім'ям, які перебувають у складних життєвих

\footnotetext{
19 Дашковська О.Р. Принципи нормотворчої діяльності : загальна характеристика. Науковий вісник Ужсгородського національного університету. Серія «Право». 2015. Вип. 35. Ч. ІІ. Т. 1. С. 31.

20 Басай О. В. Загальні засади (принципи) цивільного законодавства України : автореф. дис. ... докт. юрид. наук: 12.00.03. Одеса, 2014. С. 25.

${ }^{21}$ Мельничук С.М. Правотворча діяльність - провідна правова форма здійснення функцій держави : теоретико-прикладний аспект. Інформація і право. 2016. № 1. С. 10.
} 
обставинах ${ }^{22}$, що говорить про те, що надання соціальних послуг побудовано на гуманістичних засадах, у процесі ухвалення такого соціального акта гуманізм має виняткове значення. Це закріплено у ст. 3 Закону, де зазначено, що «надання соціальних послуг здійснюється на принципах гуманізму» ${ }^{23}$, «базуючись на принципі гуманізму, соціальна робота $\epsilon$ також засобом самореалізації людини і системою підтримки їі життєдіяльності» ${ }^{24}$. У науковому дослідженні «Гуманізм як духовно-моральний вимір соціальної роботи» автором Н.В. Шакун зазначено, що різні форми соціальної роботи створюють умови, у яких кожна людина може повною мірою виявити i реалізувати свої можливості, водночас соціальна робота $\epsilon$ практичним утіленням ідей «нового гуманізму», дієвим способом «олюднення» суспільного буття, який передбачає формування активної громадянської позиції, а «завдяки діяльності соціальних працівників у сучасному суспільстві реалізуються численні благодійні акції та громадські проєкти, налагоджується соціальні зв'язки у громаді, поліпшується життя людей» ${ }^{25}$.

У наукових розвідках Л.П. Шумної щодо гуманності як принципу соціального обслуговування зазначено, що даний принцип передбачає «передусім, терпиме ставлення до набувача послуг, незалежно від того, хто він $\epsilon$ - інвалід, пенсіонер, неповнолітній, бездомний» ${ }^{26}$, працівник соціальної служби має дотримуватися вимог гуманізму й милосердя, адже громадяни мають право на шанобливе й гуманне ставлення до себе з боку соціальних працівників. Такі пропозиції належать більше до морально-етичних норм поведінки соціальних працівників, а не до вимог принципу гуманності як принципу правотворчості в галузі права соціального забезпечення.

О.В. Тищенко в результаті розгляду проблеми теоретичного змісту поняття права соціального забезпечення як самостійної галузі права, дослідження плюралізму поглядів щодо підстав для формування сучасного доктринального розуміння поняття права соціального забезпечення зазначено, що «за своєю природою та соціальним призначенням право соціального забезпечення має гуманістичний характер» ${ }^{27}$.

У зв'язку із цим слушними є висновки О.С. Поліщука про те, що суспільство складається з різних соціальних груп, які створюють соціальну систему, усі елементи якої взаємодіють один 3 одним, що породжує

\footnotetext{
22 Про соціальні послуги : Закон України від 17 січня 2019 р. № 2671-VIII. Дата оновлення: 01.01.2020.

${ }^{23}$ Там само.

${ }^{24}$ Шакун Н.В. Гуманізм як духовно-моральний вимір соціальної роботи. Проблеми соціальної роботи : філософія, психологія, соичілогія. 2013. № 1. С. 36.

25 Там само.

${ }^{26}$ Шумна Л.П. Доступність і гуманність як принципи соціального обслуговування. Актуальні проблеми права: теорія і практика. 2013. № 27. С. 608.

${ }^{27}$ Тищенко О.В. Поняття права соціального забезпечення : теоретичні аспекти. Науковий вісник Ужгородського національного університету. Серія «Право». 2014. Вип. 26. С. 118.
} 
колективну дію; ефективність напряму такої дії та злагодженість функціонування всього соціального організму залежать від тісної співпраці індивідів і соціальних структур, яка, у свою чергу, базується на принципі гуманізму ${ }^{28}$.

\section{3. Відображення гуманізму як принципу правотворчості у кримінальному й адміністративному праві}

Стосовно відображення вимог гуманізму як принципу правотворчої діяльності в галузі кримінального права в науковій літературі висвітлені різні погляди. Наприклад, С.В. Чабур щодо сфери кримінального права 3 посиланням на інших авторів зазначає, що реалізація принципу гуманізму дозволяє перетворити кримінальне право з репресивного інструменту на інструмент профілактики та запобігання злочинності. Дієвість принципу гуманізму у кримінальному праві «проявляється в застосуванні максимально м'яких форм кримінально-правового впливу 3 метою забезпечення не стільки покарання, скільки перевиховання правопорушника» ${ }^{29}$, допомагає підвищити загальну ефективність боротьби зі злочинністю. Проте вимоги принципу гуманізму реалізовано в багатьох інститутах кримінального права.

Професор Н.А. Орловська у процесі розгляду актуальних аспектів розвитку кримінального законодавства України в контексті гуманізації та лібералізації зазначено, що останні зумовлені вираженою характерністю та видимістю їхнього впливу на формування нормативного тексту.

Авторкою зазначено, що «гуманізація - це сфера визначення специфіки заходів кримінально-правового впливу. У цьому плані пом'якшення покарання далеко не повністю вичерпує смислове навантаження гуманізації. Остання являє собою проблему, вирішення якої має будуватися не тільки на пом'якшенні кримінально-правового впливу на особу, яка вступила в конфлікт із законом, але й на розширенні можливостей захисту прав та інтересів потерпілих від кримінальних діянь» ${ }^{30}$.

Отже, з одного боку, принцип гуманізму звернено до потерпілих від злочинів і передбачає захист життя, здоров'я, прав і свобод громадян від злочинних посягань. 3 іншого боку, принцип гуманізму звернено до осіб, які порушили кримінальний закон, що може призвести до порушення принципу справедливості. Справді, застосування максимально м'яких форм кримінально-правого впливу до злочинця, звільнення його від

\footnotetext{
${ }^{28}$ Поліщук О.С. Принцип гуманізму в колективній дії. Філософія науки: традищії та інноващії. 2014. № 1. C. 161 .

${ }^{29}$ Чабур С.В. Принципи правотворчості. Вісник Чернівецького факультету Наџіонального університету «Одеська юридична академія». 2017. Вип. 2. С. 69.

${ }^{30}$ Орловська Н.А. Лібералізація чи гуманізація: до питання про тренд розвитку кримінального законодавства України. Вісник Південного регіонального иентру Національної академії правових наук Украӥни. 2016. № 6. С. 95-96.
} 
відповідальності і гуманне ставлення до нього може позбавити потерпілого відчуття справедливості. У науковому дослідженні щодо співвідношення принципів гуманізму і справедливості як принципів кримінального права автором Ю.С. Тимощук зазначено, що реалізація принципу гуманізму не повинна суперечити принципу справедливості, ні принцип гуманізму, ні принцип справедливості не можуть мати пріоритетне місце в системі принципів кримінального права ${ }^{31}$.

Багато теоретичних і практичних проблемних питань із правозастосовної діяльності зміщуються у плоскість правотворчості. Саме на цьому етапі, під час визначення нових норм права, внесення змін в чинні або визнання такими, що втратили чинність, відповідними суб'єктами правотворчої діяльності, набагато простіше уникнути помилок і недоліків, ніж виправляти їх після набуття законом чинності та застосування його норм на практиці.

Деякі науковці вважають, що «гуманізація кримінально-правової політики повинна відбуватись шляхом: скорочення кола осіб, які підлягають кримінальній відповідальності; обмеження заходів, що застосовуються до осіб, які вчиняють кримінальні правопорушення, лише мінімально необхідними та достатніми для досягнення цілей їх виправлення та превенції; розробки та впровадження альтернативних кримінальному покаранню заходів впливу» ${ }^{32}$.

Н.А. Орловська розмірковує про лібералізацію та гуманізацію кримінального законодавства і звертає увагу на те, що є групи діянь, стосовно яких через надвисоку соціальну шкідливість та надзвичайний резонанс суттєва лібералізація та гуманізація не на часі, хоча оптимізація кримінальноправових заборон не виключається. Наприклад, корупція, державна зрада, сепаратизм тощо. Водночас «доцільність гуманізації можна обговорювати, зокрема, у плані чіткої регламентації у Кримінальному кодексі питань звільнення від покарання та його відбування для осіб, які, перебуваючи у лавах так званих «ДНР/ЛНР», не вчинили тяжких злочинів» ${ }^{33}$.

Погоджуємося 3 тим, що «кримінальне законодавство - один із наріжних каменів будь-якої правової системи, воно втілює кумулятивний ефект усього національного правового регулювання, як позитивних, так i негативних аспектів останнього» ${ }^{34}$.

\footnotetext{
${ }^{31}$ Тимощук Ю.С. Співвідношення гуманізму та справедливості як принципів кримінального права України. Правова держава. 2016. Вип. 27. С. 601.

32 Федотова Г.В. Особливості реалізації вимог принципу гуманізму у процесі запровадження інституту кримінального проступку у кримінальному праві України. Наука і правоохорона. 2015. № 4. С. 141-142.

${ }^{33}$ Орловська Н.А. Лібералізація чи гуманізація: до питання про тренд розвитку кримінального законодавства України. Вісник Південного регіонального центру Національної академії правових наук України. 2016. № 6. С. 98.

${ }^{34}$ Там само. С. 93.
} 
Справді кримінальне право характеризується високою бланкетністю кримінально-правових заборон, а кримінально-правові положення залежать від юридичних приписів інших галузей права, тому кримінально-правові приписи вимушено «накопичують», серед іншого, недоліки та суперечності, притаманні так званим позитивним сферам регулювання ${ }^{35}$. Деякі автори зазначають, що «принцип гуманізму імплементується в одну із загальних засад кримінального провадження - верховенство права» ${ }^{36}$, коли кримінальне провадження відбувається 3 додержанням принципу верховенства права, тобто людина, іiі права та свободи визнаються найвищими цінностями. У Кримінальному процесуальному кодексі складові частини принципу гуманізму охоплюють такі засади кримінального провадження, як рівність перед законом і судом, повага до людської гідності, забезпечення права на свободу й особисту недоторканність, недоторканність житла й іншого володіння особи, невтручання у приватне життя, недоторканність права власності тощо ${ }^{37}$.

Сучасний погляд на принцип гуманізму кримінального права пов'язаний 3 піклуванням держави про безпеку людини, 3 людяністю, повагою до людської гідності. У процесі правотворчості сутність принципу гуманізму розкривається через такі вимоги, як забезпечення охорони людини, захист іiі життя, здоров'я, честі і гідності; призначення покарання, необхідного і достатнього для виправлення особи, яка вчинила кримінальне правопорушення; передбачені звільнення від кримінальної відповідальності, від покарання чи його відбування, а також заміна покарання більш м'яким; передбачено, що покарання й інші кримінально-правові заходи, що застосовуються до особи, не можуть мати своїм змістом завдання фізичних страждань чи приниження людської гідності тощо.

І.Л. Беспалько розмірковує над питанням гуманізму у кримінальному процесі та зауважує, що даний принцип є одним із загальноправових, фундаментальних засад, відповідно до яких формується система принципів певної галузі права, утілюється він у низці нормативних приписів різноманітної галузевої належності. Кримінально-процесуальна діяльність, як зазначає автор, вирізняється особливостями, притаманними лише цій галузі права, під час розгляду окремих принципів кримінального процесу ми можемо виявити в їхньому змісті відповідні гуманістичні прояви. Так, у процесі кримінального провадження принцип гуманізму виявляється

\footnotetext{
${ }^{35}$ Орловська Н.А. Лібералізація чи гуманізація: до питання про тренд розвитку кримінального законодавства України. Вісник Південного регіонального центру Національної академії правових наук Украӥни. 2016. № 6. С. 93.

${ }^{36}$ Косович В.М. Принципи права, принципи правотворчості та принципи в нормативно-правових актах. Вісник Львівського університету. Серія «Юридична». 2016. Вип. 63. С. 5.

37 Там само. С. 5.
} 
в доступності правосуддя; в обов'язку органів, що ведуть процес, гуманно ставитися до всіх осіб, які беруть участь у кримінально-процесуальному провадженні, тобто визнавати самоцінність людської особистості, невід'ємність іï прав і свобод; у недопустимості зазнання цими особами катувань чи жорсткого, нелюдського або такого, що принижує їхню честь і гідність, поводження. Автором зазначено, що «дані вимоги спрямовують кримінально-процесуальну діяльність на охорону прав та свобод людини i громадянина, підкреслюють водночас важливість етичного, морального їх захисту» ${ }^{38}$.

Щодо сфери кримінально-виконавчого права, можемо констатувати, що принцип гуманізму втілюється в особливому підході до застосування санкцій кримінальної норми, що передбачає не тільки і не стільки покарання злочинця, скільки його виправлення та повернення в суспільство як повноцінного індивіда ${ }^{39}$. Проте іншими авторами зазначено, що «гуманізм як правова категорія кримінально-виконавчого права характеризується двома напрямами, що стосуються інтересів як суспільства, так і засудженого» ${ }^{40}$, i вони взаємопов'язані. Отже, перед державою в особі законодавчого органу у процесі правотворчості стоїть складне і неоднозначне завдання. Законодавець, коли формує кримінально-виконавчу політику і запроваджує елементи гуманізації стосовно засуджених до позбавлення волі, 3 одного боку, а з іншого - коли забезпечує захист кожного члена суспільства, має вжити заходів щодо механізму реалізації вимог принципу гуманізму.

М.C. Пузирьов та М.I. Лисенко вважають, що йдеться про осіб, які безпосередньо реалізують принцип гуманізму стосовно засуджених, це кваліфіковані кадри $з$ достатнім матеріальним забезпеченням. «Особа з відповідним рівнем освіти та матеріальним забезпеченням, спокійна й урівноважена, зможе виконувати покарання відповідно до міжнародних пенітенціарних стандартів» ${ }^{41}$. Погоджуємося, що саме принцип гуманізму якнайкраще розкриває ставлення суспільства до особи, яка вчинила кримінально карне діяння, і свідчить про дотримання міжнародних правових актів. Зокрема, «Україна, будучи учасником Міжнародного пакту про громадські та політичні права, Конвенції ООН проти катувань i Європейської конвенції захисту прав людини та основоположних свобод, зобов'язана гарантувати право не бути підданим катуванням та поганому

\footnotetext{
38 Беспалько І.Л. Принцип гуманізму в кримінальному процесі України. Проблеми законності. 2011. Вип. 113. С. 147-148.

${ }^{39}$ Чабур С.В. Принципи правотворчості. Вісник Чернівецького факультету Національного університету «Одеська юридична академія». 2017. Вип. 2. С. 69.

40 Пузирьов М.С., Лисенко М.І. Реалізація принципу гуманізму виконання і відбування покарання в умовах ізоляції засуджених. Право і суспільство. 2012. № 6. С. 144.

41 Там само.
} 
поводженню 3 боку державних службовців» ${ }^{42}$. Реалізація вимог принципу гуманізму під час виконання покарання важлива i тим, що характеризує кримінально-виконавчу політику держави, і законодавцю набагато простіше запобігти помилкам на етапі правотворчої діяльності, ніж виправляти їх після набуття законом чинності та застосування його норм на практиці.

У науковому дослідженні щодо співвідношення принципів гуманності й ефективності під час притягнення неповнолітніх до кримінальної відповідальності Н.В. Ортинська звертає увагу на наявність колізії між принципом гуманності щодо неповнолітніх і ефективністю кримінального правосуддя.

Авторка дійшла висновків, що гуманізм у застосуванні щодо неповнолітніх кримінальної відповідальності є справді необхідним заходом, що продиктовано нормами міжнародного та вітчизняного законодавства, адже неповнолітні є особливими учасниками суспільного життя, а мета покарання - це виправлення, перевиховання засуджених та запобігання вчиненню нових злочинів. I все ж таки ті санкції, що застосовуються до неповнолітніх, мають відповідати принципу гуманності, але бути ефективними. Так, неефективними є примусові заходи виховного характеру, що застосовуються до особи в разі звільнення від кримінальної відповідальності, а кращим варіантом може бути застосування покарання у вигляді громадських робіт ${ }^{43}$.

У науковому дослідженні принципу гуманізму у кримінальному праві О.С. Олійник підсумовує, що, «по-перше, не потрібно забувати, що універсальним засадничим положенням кримінального права $\epsilon$ його справедливість; а по-друге, повинен існувати здоровий компроміс між правами і свободами осіб, які вчинили суспільно небезпечне діяння, правами і свободами потерпілих осіб, суспільства, держави та інтересами осіб, які тією чи іншою мірою залежать від подальшої долі самого засудженого» ${ }^{44}$.

У результаті проведення дослідження відображення принципу гуманізму у кримінальному праві Л.Ю. Тімофєєвою зазначено, що «необхідно оптимізувати й удосконалювати збалансовану реалізацію принципу гуманізму у кримінальному праві відповідно до окремих інститутів кримінального права» ${ }^{45}$. Цілком погоджуємося 3 такою думкою і вважаємо, що ключовим

\footnotetext{
${ }^{42}$ Пузирьов М.С., Лисенко М.I. Реалізація принципу гуманізму виконання і відбування покарання в умовах ізоляції засуджених. Право і суспільство. 2012. № 6. С. 142.

${ }^{43}$ Ортинська Н.В. Співвідношення принципів гуманності та ефективності при притягненні неповнолітнього до кримінальної відповідальності. Вісник Національного університету «Львівська політехніка». Серія «Юридичні науки». 2016. № 837. С. 308.

${ }^{44}$ Олійник О.С. Принцип гуманізму в кримінальному праві України. Підприємництво, господарство $i$ право. 2018. № 12. С. 288.

45 Тімофєєва Л.Ю. Відображення принципу гуманізму в кримінальному законі : порівняльно-правова характеристика. Науковий вісник Міжнародного гуманітарного університету. Серія «Юриспруденція». 2014. Вип. 10-2 (2). С. 96.
} 
питанням під час реалізації принципу гуманізму у правотворчій діяльності в галузі кримінального права $є$ досягнення балансу інтересів усіх суб'єктів кримінально-правових відносин.

У процесі розгляду реалізації вимог гуманізму у сфері адміністративного права звернемося до наукового дослідження С.Ю. Беньковського, який у результаті вивчення прояву гуманізму як загальносоціального принципу провадження у справах про адміністративні правопорушення дійшов висновків, що «гуманна поведінка повинна бути притаманна особі, що здійснює провадження, на всіх стадіях провадження справи: від виявлення правопорушення до виконання адміністративного стягнення» ${ }^{46}$. Інакше порушується і гальмується реалізація принципу гуманізму, який, окрім вищезазначеного, виступає ще і критерієм правильності рішення, оскільки «достеменно визначена істина у справі має оцінюватись згідно 3 моральними принципами» ${ }^{47}$.

Отже, украй важливим $є$ законодавче закріплення принципу гуманізму у провадженнях у справах про адміністративні правопорушення. Він не обов'язково має бути безпосередньо виписаний у Кодексі України про адміністративні правопорушення, але він має обов'язково випливати зі змісту норм, якими регулюється провадження, а також із бланкетних норм, установлених низкою статей даного Кодексу.

Цікавим є наукове дослідження професора В.I. Барко, яким зазначено, що «для ефективного керівництва необхідна реалізація важливого принципу й умови ефективного управління персоналом - гуманістичного особистісно орієнтованого підходу до працівників організації» ${ }^{48}$. Цей підхід автор розглядає переважно щодо системи Міністерства внутрішніх справ, проте вважаємо доцільним його розглянути 3 підкресленням прояву $\mathrm{i}$ відображення вимог гуманізму саме як принципу підзаконної правотворчої діяльності таких суб’єктів, як центральні та місцеві органи виконавчої влади (Кабінет Міністрів України, місцеві адміністрації), органи місцевого самоврядування, адміністрації підприємств, установ, організацій тощо. Результатом підзаконної правотворчої діяльності цих органів і посадових осіб $є$ видання підзаконного акта, який ухвалюється на підставі закону, відповідно до закону і в порядку його виконання.

Отже, гуманістичний особистісно орієнтований підхід, на думку автора, передбачає притаманну кожній людині актуальну тенденцію - рости,

\footnotetext{
46 Беньковський С.Ю. Принцип гуманізму як загальносоціальний принцип проваджень у справах про адміністративні правопорушення. Форум права. 2007. № 3. С. 47.

47 Там само.

${ }^{48}$ Барко B.I. Гуманістичний особистісно орієнтований підхід як принцип ефективного управління персоналом органів внутрішніх справ. Вісник Академії управління Міністерства внутрішніх справ. 2008. № 3. C. 116.
} 
розвиватись, реалізовувати свій потенціал; конструктивне прагнення кожного працівника до прогресу і саморозвитку. Практичне втілення таких вимог можливе за умови створення управлінцем системи підвищення кваліфікації і розвитку, мотивації персоналу, потрібні «позитивне ставлення керівника до працівника організації, безумовне сприйняття його як людини 3 певними інтересами, мотивами і потребами, емпатійне розуміння, використання в роботі комплексу методів впливу на особистість, серед яких переважають методи i засоби заохочення i стимулювання діяльності, а також створення умов для командної роботи, постійного особистісного зростання і розвитку працівників» ${ }^{49}$. Автором підкреслено, що цей принцип на практиці не завжди втілено, і тому вкрай важливе вирішення цієї проблеми на етапі підзаконної правотворчості. Гуманізм як принцип правотворчої діяльності спрямовує державну діяльність на визнання людини найвищою цінністю, на охорону іiі прав та свобод.

\section{ВИСНОВКИ}

Отже, вивчення наукових позицій вітчизняних авторів щодо теоретичних засад гуманізму як принципу правотворчої діяльності, а також аналіз досліджень щодо відображення і впливу деяких його вимог у різних галузях права дозволяють зробити деякі висновки й узагальнення.

1. В аспекті нашого дослідження вихідними $є$ положення про те, що принцип гуманізму, на основі якого має здійснюватися правотворча діяльність всіма уповноваженими суб'єктами, - це гуманістичний зміст норми права. Він передбачає певні вимоги, зокрема щодо адекватного відображення у змісті нормативно-правових актів загальнолюдських цінностей, закріплення в них основних соціальних умов ефективної реалізації прав і свобод людини і громадянина, їхню рівність, вчасний захист та відповідність ухвалених нормативно-правових актів міжнародним договорам і стандартам.

Під час підготовки проєктів нормативно-правових актів різними уповноваженими суб'єктами обов'язковою передумовою їхньої високої якості, повноти й узгодженості $є$ точне і неухильне дотримання вимог принципу гуманізму. 3 огляду на очевидні відмінності між усіма принципами правотворчості, їхню неоднакову суть i змістовість, спрямованість та значення, очевидною є деяка змістова близькість між ними саме завдяки принципу гуманізму. Реалізація всіх інших основоположних принципів правотворчої діяльності, їх трансформація й імплементація у

\footnotetext{
49 Барко B.І. Гуманістичний особистісно орієнтований підхід як принцип ефективного управління персоналом органів внутрішніх справ. Вісник Академії управління Міністерства внутрішніх справ. 2008. № 3. C. 129.
} 
праворегулятивну плоскість відбуваються на основі і за допомогою принципу гуманізму. Це показник належної ефективної роботи з ухвалення нормативно-правових актів та їх оформлення. Інакше недооцінка та неврахування вимог принципу гуманізму спричинять недоліки й упущення в кожній конкретній галузі законодавства.

2. У правотворчій діяльності принцип гуманізму є фундаментом і має однаковий прояв абсолютно в усіх галузях права, проте відображення i вплив деяких його вимог різняться. Це залежить від специфіки і характеру правовідносин тієї чи іншої галузі права, а також способів владного впливу на ці відносини, тобто від предмета і метода правового регулювання.

Звернено увагу на те, що принципи права, принципи правотворчості та принципи, закріплені в нормативно-правових актах, не існують зовсім ізольовано, а навпаки - мають властивість взаємопроникнення.

Реалізація всіх вимог принципу гуманізму забезпечується і гарантується насамперед Конституцією України, де визначено пріоритет загальнолюдських цінностей, закріплено принципи соціальної справедливості, утверджений демократичний і гуманістичний вибір народу України, задекларовано прихильність України до загальновизнаних норм міжнародного права. Для цивільного права гуманістичний зміст норми права передбачає юридичну рівність учасників цивільних правовідносин, їхнє вільне волевиявлення, майнову самостійність тощо. Для кримінального та кримінально-виконавчого права головною засадою є справедливість, і реалізація принципу гуманізму дозволяє перетворити кримінальне право з репресивного інструменту на інструмент профілактики та запобігання злочинності. Підкреслено, що найголовнішою в кожній галузі права $є$ реалізація вимог принципу гуманізму таким чином, щоби створити адекватний баланс інтересів усіх учасників правовідносин, рівність сторін, неможливість зовнішнього примусу тощо.

\section{АНОТАЦІЯ}

Дане монографічне дослідження $\epsilon$ логічним продовженням раніше проведених наукових розвідок правотворчості та іiї принципів. Зокрема, воно базується на результатах попередніх наукових досліджень законності і гуманності як принципів правотворчості, відображення їхніх вимог в окремих галузях права.

Багато теоретичних і практичних проблемних питань із правозастосовної діяльності зміщуються у площину правотворчості. Саме на цьому етапі, під час установлення нових норм права, унесення змін в чинні або визнання такими, що припинили свою дію, відповідними суб'єктами правотворчої діяльності, набагато простіше уникнути помилок і недоліків, ніж виправляти їх після набуття законом чинності та застосування його норм на практиці. 
Здійснено теоретико-правовий аналіз вимог принципу гуманізму у процесі правотворчості. Звернено увагу на те, що вони передбачають адекватне відображення у змісті нормативно-правових актів загальнолюдських цінностей, закріплення в них основних соціальних умов ефективної реалізації прав i свобод людини і громадянина, їхню рівність, вчасний захист та відповідність ухвалених нормативно-правових актів міжнародним договорам і стандартам.

Акцентовано на тому, що реалізація всіх інших основоположних принципів правотворчої діяльності, їх трансформація й імплементація у праворегулятивну площину відбуваються на основі i за допомогою принципу гуманізму. Це показник належної ефективної роботи з ухвалення нормативно-правових актів та їх оформлення, недооцінка та неврахування вимог принципу гуманізму спричинять недоліки й упущення в кожній конкретній галузі законодавства.

Визначено, що відображення і вплив деяких вимог гуманізму як принципу правотворчості в різних галузях права різняться. Це залежить від специфіки і характеру правовідносин тієї чи іншої галузі права, а також способів владного впливу на ці відносини, тобто від предмета і метода правового регулювання.

\section{ЛIТЕРАТУРА}

1. Амеліна А.С. Принципи кодифікації цивільного законодавства. Науковий вісник Ужгородського національного університету. Серія «Право». 2015. Вип. 30 (1). С. 106-109. URL: http://nbuv.gov.ua/UJRN/ nvuzhpr_2015_30\%281\%29_27 (дата звернення: 20.08.2020).

2. Барко B.I. Гуманістичний особистісно орієнтований підхід як принцип ефективного управління персоналом органів внутрішніх справ. Вісник Академії управління Міністерства внутрішніх справ. 2008. № 3. С. 115-129. URL: http://nbuv.gov.ua/UJRN/ucnavs_2008_3_11 (дата звернення: 25.08.2020).

3. Басай О.В. Загальні засади (принципи) цивільного законодавства України : автореф. дис. ... докт. юрид. наук: 12.00.03. Одеса, 2014. 36 с.

4. Беньковський С.Ю. Принцип гуманізму, як загальносоціальний принцип проваджень у справах про адміністративні правопорушення. Форум права. 2007. № 3. С. 44-47. URL: http://nbuv.gov.ua/UJRN/ FP_index.htm_2007_3_10 (дата звернення: 10.08.2020).

5. Беспалько І.Л. Принцип гуманізму у кримінальному процесі України. Проблеми законності. 2011. Вип. 113. С. 140-149. URL: http://nbuv.gov.ua/ UJRN/Pz_2011_113_18 (дата звернення: 20.08.2020).

6. Гетьман Є.А. Принцип верховенства права у нормотворчій діяльності органів виконавчої влади. Проблеми законності. 2016. Вип. 134. С. 61-69. 
7. Дашковська О.Р. Принципи нормотворчої діяльності: загальна характеристика. Науковий вісник Ужгородського національного університету. Серія «Право». 2015. Вип. 35. Ч. II. Т. 1. С. 29-32. URL: file:///C:/Users/Asus/ Downloads/nvuzhpr_2015_35(2.1)_8.pdf(дата звернення: 11.08.2020).

8. Жуков С.М. Гуманізм як феномен, як світоглядний принцип нової парадигми освіти; гуманістичне виховання, становлення підростаючої особистості. Педагогічна освіта: теорія і практика. 2011. Вип. 9. С. 37-46. URL: http://nbuv.gov.ua/UJRN/znppo_2011_9_8 (дата звернення: 12.08.2019).

9. Конєва Н.В. Природно-правовий зміст правового закону. Науковий вісник Національної академії внутрішніх справ. 2013. № 2. C. 95-100. URL: http://nbuv.gov.ua/UJRN/Nvknuvs_2013_2_16 (дата звернення: 13.09.2020).

10. Конституція України, прийнята 28 червня 1996 р., 3 наст. змінами. URL: https://zakon.rada.gov.ua/laws/show/254\%D0\%BA/96-\%D0\%B2\%D1\%80 (дата звернення: 10.09.2020).

11. Косович В.М. Принципи права, принципи правотворчості та принципи у нормативно-правових актах. Вісник Львівського університету. Серія «Юридична». 2016. Вип. 63. С. 3-9. URL: http://nbuv.gov.ua/UJRN/Vlnu_yu_ 2016_63_3 (дата звернення: 19.08.2020).

12. Мельничук С.М. Правотворча діяльність - провідна правова форма здійснення функцій держави : теоретико-прикладний аспект. Інформація $i$ право. 2016. № 1. С. 5-11 URL: http://nbuv.gov.ua/UJRN/Infpr_2016_1_3 (дата звернення: 20.08.2020).

13. Нікітенко В.О. Гуманізм як фундаментальна тенденція суспільного розвитку: теорія та практика. Гуманітарний вісник Запорізької державної інженерної академії. 2005. Вип. 22. C. 177-185. URL: http://nbuv.gov.ua/ UJRN/znpgvzdia_2005_22_19 (дата звернення: 20.08.2020).

14. Олійник О.С. Принцип гуманізму у кримінальному праві України. Підприємниитво, господарство $і$ право. 2018. № 12. С. 286-289. URL: http://pgp-journal.kiev.ua/archive/2018/12/55.pdf (дата звернення: 18.08.2020).

15. Орловська Н.А. Лібералізація чи гуманізація: до питання про тренд розвитку кримінального законодавства України. Вісник Південного регіонального центру Національної академії правових наук України. 2016. № 6. C. 93-100. URL: http://nbuv.gov.ua/UJRN/vprc_2016_6_14 (дата звернення: 19.08.2020).

16. Ортинська Н.В. Співвідношення принципів гуманності та ефективності при притягненні неповнолітнього до кримінальної відповідальності Вісник Начіонального університету «Львівська політехніка». Серія «Юридичні науки». 2016. № 837. С. 304-308. URL: http://nbuv.gov.ua/UJRN/vnulpurn_ 2016_837_51 (дата звернення: 22.08.2020). 
17. Особливості і проблеми розвитку правотворчості в сучасних умовах: монографія / О.І. Донченко та ін. ; за заг. ред. В.П. Плавича. Одеса : Фенікс, 2018. 348 c.

18. Поліщук О.С. Принцип гуманізму в колективній дії. Філософія науки : традииіï та інноваиіï. 2014. № 1. C. 152-162. URL: http://nbuv.gov.ua/UJRN/ FilosNauk_2014_1_20 (дата звернення: 22.08.2020).

19. Про соціальні послуги : Закон України від 17.01.2019 р. № 2671-VIII. Дата оновлення: 01.01.2020. URL: https://zakon.rada.gov.ua/laws/show/2671-19 (дата звернення: 19.08.2019).

20. Пузирьов М.С., Лисенко М.I. Реалізація принципу гуманізму виконання і відбування покарання в умовах ізоляції засуджених. Право $i$ суспільство. 2012. № 6. С. 141-145. URL: http://nbuv.gov.ua/UJRN/Pis_ 2012_6_31 (дата звернення: 23.08.2019).

21. Ричко О.В. Принцип гуманізму в публічній політиці. Збірник наукових праџьь Національної академії державного управління при Президентові України. 2012. Вип. 2. С. 221-229. URL: http://nbuv.gov.ua/UJRN/znpnadu_ 2012224 (дата звернення: 22.08.2020).

22. Сисак М.М. Гуманізм у контексті глобалістики. Гілея : науковий вісник. 2014. Вип. 80. С. 300-304. URL: http://nbuv.gov.ua/UJRN/gileya_ 2014_80_79 (дата звернення: 20.08.2020).

23. Славова Н.О. Антропоцентризм як принцип правотворчості. Правничий часопис Донеиького університету. 2013. № 1. С. 134-142. URL: http://nbuv.gov.ua/UJRN/Pchdu_2013_1_22 (дата звернення: 21.08.2020).

24. Тесленко М.В. Презумпція правового характеру законів у правовій державі. Актуальні проблеми держави і права. 2004. Вип. 22. С. 225-229. URL: http://nbuv.gov.ua/UJRN/apdp_2004_22_42 (дата звернення: 24.08.2020).

25. Тімофєєва Л.Ю. Відображення принципу гуманізму в кримінальному законі: порівняльно-правова характеристика. Науковий вісник Міжнародного гуманітарного університету. Серія «Юриспрудениія». 2014. Вип. 10-2 (2). С. 94-97. URL: http://nbuv.gov.ua/UJRN/Nvmgu_jur_2014_102\%282\%29_28 (дата звернення: 21.08.2020).

26. Тимощук Ю.С. Співвідношення гуманізму та справедливості як принципів кримінального права України. Правова держава. 2016. Вип. 27. C. 595-602. URL: http://nbuv.gov.ua/UJRN/PrDe_2016_27_78 (дата звернення: 20.08.2020).

27. Тищенко О.В. Поняття права соціального забезпечення: теоретичні аспекти. Науковий вісник Ужгородського наиіонального університету. Серія «Право». 2014. Вип. 26. С. 115-119. URL: https://dspace.uzhnu.edu.ua/ jspui/bitstream/lib/7931/1/\%D0\%9F\%D0\%9E\%D0\%9D\%D0\%AF\%D0\%A2\%D0 \%A2\%D0\%AF\%20\%D0\%9F\%D0\%A0\%D0\%90\%D0\%92\%D0\%90\%20\%D0\% 
A1\%D0\%9E\%D0\%A6\%D0\%86\%D0\%90\%D0\%9B\%D0\%AC\%D0\%9D\%D0\%9 E\%D0\%93\%D0\%9E\%20\%D0\%97\%D0\%90\%D0\%91\%D0\%95\%D0\%97\%D0\% 9F\%D0\%95\%D0\%A7\%D0\%95\%D0\%9D\%D0\%9D\%D0\%AF.pdf (дата звернення: 19.08.2020).

28. Федотова Г.В. Особливості реалізації вимог принципу гуманізму у процесі запровадження інституту кримінального проступку в кримінальному праві України. Наука і правоохорона. 2015. № 4. C. 139-143. URL: http://nbuv.gov.ua/UJRN/Nip_2015_4_23 (дата звернення: 29.08.2020).

29. Чабур С.В. Принципи правотворчості. Вісник Чернівецького факультету Національного університету «Одеська юридична академія». 2017. Вип. 2. С. 64-74. URL: http://nbuv.gov.ua/UJRN/vchfo_2017_2_8 (дата звернення: 22.08.2020).

30. Чеботарьов С.С. Гуманізм як принцип права України. Актуальні проблеми держави і права. 2012. Вип. 65. С. 205-210. URL: http://nbuv.gov.ua/ UJRN/apdp_2012_65_26 (дата звернення: 24.08.2020).

31. Чепульченко Т.О. Верховенство права як основоположний принцип сучасного правотворення. Вісник Наџіонального технічного університету Украӥни «Київський політехнічний інститут». Серія «Політологія. Соціологія. Право». 2012. № 3. С. 185-188. URL: http://nbuv.gov.ua/UJRN/ VKPI_soc_2012_3_36 (дата звернення: 20.08.2020).

32. Шакун Н.В. Гуманізм як духовно-моральний вимір соціальної роботи. Проблеми соиіальної роботи: філософія, психологія, сочіологія. 2013. № 1. C. 33-36. URL: http://nbuv.gov.ua/UJRN/prcr_2015_1_8 (дата звернення: 19.08.2020).

33. Шумна Л.П. Доступність і гуманність як принципи соціального обслуговування. Актуальні проблеми права: теорія і практика. 2013. № 27. C. 604-609. URL: http://nbuv.gov.ua/UJRN/app_2013_27_81 (дата звернення: 19.08.2020).

34. Юхимюк О.М. Способи викладу принципів права у нормативноправових актах. Історико-правовий часопис. 2014. № 2. С. 23-27. URL: http://nbuv.gov.ua/UJRN/ipch_2014_2_7 (дата звернення: 19.08.2020).

\section{Information about author: Donchenko O. I.,}

Candidate of Law, Associate Professor, Associate Professor at the Department of General Legal Disciplines and International Law

Odesa I. I. Mechnikov National University 24/26, Frantsuzskiy blvd., Odesa, 65058, Ukraine 